\title{
Global imbalances: benign by-product of global development or toxic consequence of corporate globalization?
}

\author{
Thomas I. Palley \\ Senior Economic Policy Adviser, AFL-CIO, Washington, DC, USA
}

This paper explores and contrasts the revised Bretton Woods hypothesis (BW II) with the structural Keynesian hypothesis. Whereas the former sees the growing global imbalances of the 3 decades prior to the financial crisis of 2008 as beneficial, the latter sees them as problematic and destructive of shared prosperity in the United States. Moreover, the US economic relationship with China is viewed as especially problematic as it involves the largest bi-lateral trade deficit, and because it has also been a major source of investment diversion and manufacturing job loss. The paper concludes that the BW II analogy between today's global financial system and the original Bretton Woods system is without foundation, but that it survives because the hypothesis helps rationalize and justify large trade deficits and the process of corporate globalization.

Keywords: revised Bretton Woods hypothesis, structural Keynesian hypothesis, global imbalances, US trade deficit

JEL codes: F02, F32, F33

\section{THE POLITICAL ECONOMY OF THE BRETTON WOODS II HYPOTHESIS}

The revised Bretton Woods hypothesis (BW II) advanced by economists Michael Dooley, David Folkerts-Landau, and Peter Garber $(2003$; 2004) is one of a family of hypotheses developed in the 2000s to explain the US trade deficit as a beneficial phenomenon for both the US and global economies. By rationalizing the trade deficit as beneficial, the hypothesis has given support to mainstream economics' claim regarding the benefits of free trade and globalization. In doing so, the hypothesis has served to counter opposition to free trade and globalization which pointed to massive trade imbalances as prima facie evidence of economic damage. Because it was early in the game of trade deficit rationalization, the BW II hypothesis was quickly popularized by economists.

This paper explores and contrasts the BW II hypothesis with the structural Keynesian hypothesis (Palley 2007/2008; 2012). Whereas the former sees US trade and globalization policy of the last 3 decades as beneficial, the latter sees it as problematic and destructive of shared prosperity in the United States. Moreover, the US economic relationship with China is viewed as especially problematic, as it involves the largest bi-lateral trade deficit, and because it has also been a major source of investment diversion and manufacturing job loss.

Received 6 May 2013, accepted 6 August 2013 
The paper concludes that the analogy between today's global financial system and the original Bretton Woods system is without foundation; the BW II hypothesis was wrong before the economic crisis of 2008; and it is wrong after the crisis. That it survives is testament to the forces of ideology guiding international economics and the political usefulness of the hypothesis.

\section{WHAT IS THE GLOBAL FINANCIAL IMBALANCE PROBLEM?}

The global financial imbalance problem concerns the US trade deficit, which equals the trade surplus of the rest of the world. Figure 1 provides a heuristic map of the global economy which consists of four parts. The global economic core consists of North America, Europe, and the export-oriented emerging economies, which are placed within the triangle representing the core. The resource-based economies and less developed countries are placed outside of the core. This placement outside the core reflects the fact that the less developed economies are substantially disengaged from the core, while the resourcebased economies conform to traditional periphery status in terms of center-periphery relations. ${ }^{1}$

The bold-line triangle binding together the core represents the global production and sourcing networks established under globalization, global trade rules, and the global financial architecture governing exchange rates and international capital markets. Broadly speaking, North America has run trade deficits with all regions. Europe has run a surplus with North America and a deficit with the export-oriented economies. The export-oriented

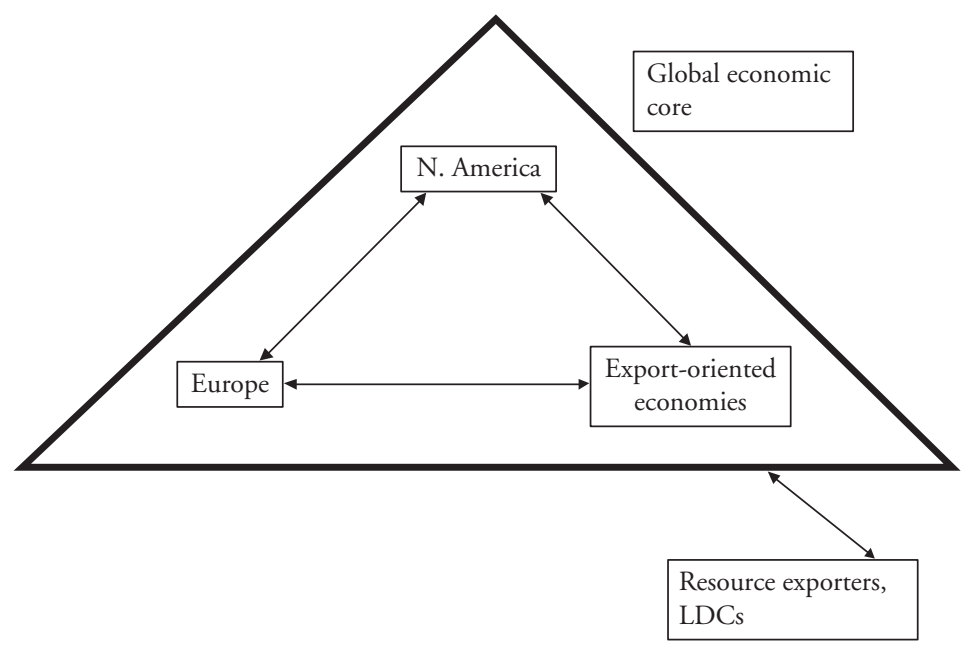

Figure 1 An economic map of the world

1. Japan, China and other East Asian economies can be considered as part of the export-oriented economies. Brazil, Russia, Australia and the Latin American economies are part of the resource-based bloc. India is a little difficult to peg. Despite its size and recent economic growth success it should probably be placed with the less developed countries because of its still relatively low level of global engagement. 
Table 1 A decomposition of the US goods trade deficit in 2007 (\$ billions)

\begin{tabular}{lcc}
\hline & \$ billions & Percent $(\%)$ \\
\hline Total & -808.8 & 100 \\
Pacific Rim & -372.3 & 46.0 \\
China & -258.5 & 32.0 \\
Canada \& Mexico & -143.0 & 17.7 \\
European Union & -110.2 & 13.6 \\
OPEC & -117.2 & 14.5 \\
Other & 192.4 & 23.8 \\
\hline
\end{tabular}

Source: Census Bureau.

economies have run surpluses with both North America and Europe. Within the North America region, the US has run large trade deficits with its NAFTA trade partners, Canada and Mexico. In recent years, the resource exporting economies have also run an aggregate trade surplus on the back of higher commodity prices.

Table 1 provides a decomposition of the US goods trade deficit in 2007, the peak year of the last business cycle prior to the onset of the Great Recession. In 2007, the US ran large trade deficits with every economic region. Pacific Rim countries (which include China, Japan, and South Korea) accounted for 46 percent of the US trade deficit, and China accounted for 32 percent of the US deficit.

\section{THE REVISED BRETTON WOODS AND OTHER MAINSTREAM HYPOTHESES}

The BW II hypothesis is part of a family of hypotheses explaining the emergence of the US trade deficit. Other explanations include the twin deficits hypothesis (Feldstein 1986), the saving shortage hypothesis, the dark matter hypothesis (Hausmann/Sturzenegger 2005), the saving glut hypothesis (Bernanke 2005), and the asset shortage hypothesis (Caballero 2006; 2007). These various hypotheses are illustrated in Figure 2, which groups them in terms of different stages of thinking about the trade deficit. Stage 1 thinking produced the twin deficits and saving shortage hypotheses. Stage 2 thinking produced the BW II hypothesis, dark matter hypothesis, saving glut hypothesis, and asset shortage hypothesis.

The twin deficits hypothesis was developed in the 1980s and maintained that the US trade deficit was caused by its purported twin, the US budget deficit. It reflects the concern of mainstream economists with the Reagan budget deficits of the 1980s. However, it fell out of favor with the Clinton budget surpluses of the 1990s that accompanied record trade deficits. Japan and Germany also consistently generated trade surpluses at the same time as they were generating increasing budget deficits.

The saving shortage hypothesis was popular in the 1990s and maintained that the US trade deficit was the result of a low US household saving rate (that is, excessive consumption). It reflects the US economic boom of the 1990s that saw a further fall in US household saving rates. However, it fell out of fashion in the 2000s as the US languished with record trade deficits, combined with demand shortage and a jobless recovery that necessitated the Federal Reserve push interest rates to record lows to spur recovery. 


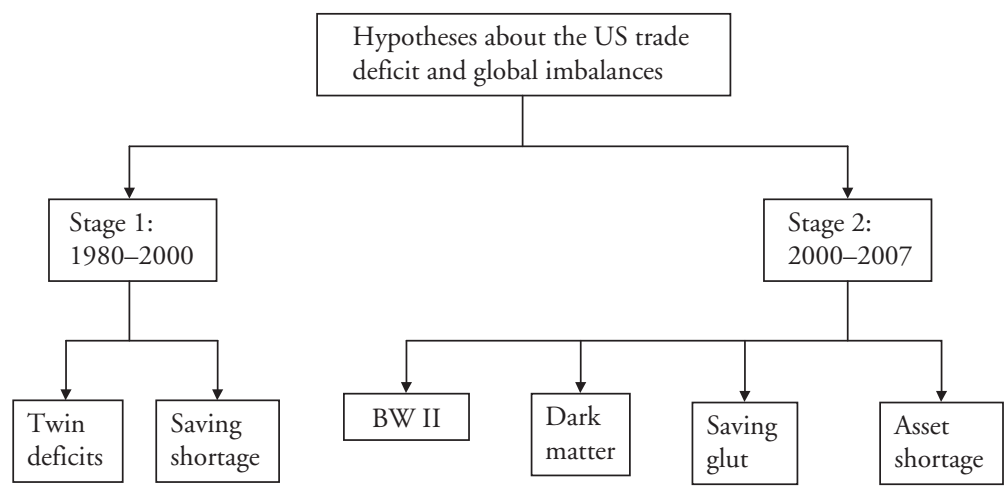

Figure 2 Mainstream explanations of the US trade deficit and global financial imbalances

The dark matter hypothesis (Hausmann/Sturzenegger 2005) was developed in the 2000s, around the same time as the BW II hypothesis. It maintains that the US trade deficit reflects the ability of the US to run a persistent trade deficit because of superior US investment returns on foreign direct investment which finances the deficit. These super-normal returns mean the US has nothing to worry about from incurring large debts to the rest of the world via the trade deficit. The dark matter hypothesis is therefore less a theory of the trade deficit, and more a theory of why the trade deficit is not a problem.

The saving glut hypothesis (Bernanke 2005) was also developed in the 2000s and maintains that the US trade deficit is the result of excessive saving by East Asian economies, particularly China. ${ }^{2}$ Finally, the asset shortage hypothesis (Caballero 2006; 2007) maintains that the world economy is suffering from a shortage of high quality financial assets owing to increased asset demand caused by rising global income, which the hypothesis attributes to globalization. It then asserts that the US has a comparative advantage in producing high quality financial assets and that the US uses this advantage to run a trade deficit. In effect, the US trades financial liabilities for goods.

The BW II hypothesis (Dooley et al. 2003; 2004) constitutes part of stage 2 thinking. In many regards, it is a pioneer in its emphasis on the role of financial assets - a role that has been taken up in the asset shortage hypothesis. According to the BW II hypothesis, globalization had created a brave new world of opportunity in which emerging markets (EM) are industrializing. As part of this process, EM countries need to acquire hard assets which supposedly provide collateral for foreign direct investment (FDI) in those economies. ${ }^{3}$

The hypothesis claims that this situation creates a parallel with the original Bretton Woods arrangement that ruled from 1945-1971. Back then, the US was the world's dominant economy, and in the late 1950s its current account started to deteriorate as

2. Bernanke et al. (2011) revisit the saving glut hypothesis, placing greater emphasis on the asset price and interest rate effects of capital inflows into the US from Europe. This later formulation moves significantly away from Bernanke's (2005) original formulation of the saving glut hypothesis, and looks a lot like conventional neo-Keynesian multi-asset analyses (Branson 1974; Tobin/Braga de Macedo 1980) that emphasize perceived differences in asset returns and the need for portfolio diversification outside of national borders.

3. Dooley et al. (2004) identify collateral with international reserves. That suggests it is governments that are posting collateral, presumably as backing to foreign investors against some form of generalized macroeconomic confiscatory default. 
Europe and Japan recovered from World War II damage, while they also borrowed from the US in order to acquire dollar balances needed to finance growing global trade. The BW II claim is that the US is now running large systematic trade deficits, this time to provide EM economies with collateral that can assist their industrialization. In this fashion, the hypothesis explains why the US is running trade deficits, and it also explains why EM economies are running trade surpluses.

A claimed strength of the hypothesis is that it explains the pattern of capital flows between the US and EM economies, which is contrary to the predictions of conventional theory that predict the reverse. According to conventional neoclassical trade theory, capital should flow from capital-abundant rich countries (for example, the US) to capital-scarce poor countries (for example, EM economies) because rates of return are higher in capitalscarce economies. According to the picture provided by the global imbalances, that is not happening. The BW II hypothesis explains why it is not happening; argues it is a good thing; and asserts that it can go on for a long while.

As for implications and predictions, the BW II hypothesis maintains that the US trade deficit is unproblematic and stands to continue for a considerable while longer. From a historical vantage, the comparison is with 1958 rather than 1971, the year of demise of the original Bretton Woods system. The argument is that developing countries still have a long way to go with their development projects and still need to accumulate considerably more collateral to support their development plans. Consequently, they will continue to run trade surpluses and the US will continue to run trade deficits long into the future. At some future date that process will end, once EM economies have fully emerged and have no further need for additional collateral. At that time, the dollar should start to weaken, the US trade deficit should start to correct, and the global imbalance problem should self-correct.

The variety of explanations of the US trade deficit, with their different reasoning, reflects the political economy that has driven mainstream economic analysis of the US trade deficit and global imbalances. The BW II hypothesis, dark matter hypothesis, saving glut hypothesis, and asset shortage hypothesis all attempt to introduce both financial factors and the effects of globalization into discussion of the US trade deficit. A striking feature is that all except the saving glut hypothesis view the trade deficit as benign and even benevolent. The US is taking advantage of its comparative advantage in investment and production of financial assets and engaging in welfare-enhancing trade.

Moreover, all four hypotheses, including the saving glut hypothesis, assert that globalization has been good for the US economy and that existing trade and globalization policy should be continued. The BW II hypothesis says trade deficits are the way to promote global economic development, including US economic growth. The dark matter hypothesis says the deficit is unproblematic and fully paid for by super-normal returns on US FDI. The asset shortage hypothesis claims the trade deficit and asset price bubbles are the way to solve the asset shortage problem. The saving glut hypothesis urges China to reduce its saving, but is not critical of globalization and the trading regime. According to its reasoning, China is in fact providing the US with a 'free lunch' by dumping goods below marginal cost and by lending at ultra-low real interest rates. The only damage from the trade deficit is the result of financial market failure in the US, which may have resulted in misallocation of resources borrowed from China. ${ }^{4}$

In sum, all four hypotheses cheerlead for free trade and globalization. Three of the four present the trade deficit as benign, thereby rationalizing policymaker indifference to the

4. All of the hypotheses adopt a loanable funds approach to trade deficits and surpluses, the macroeconomic effects of which are manifested via interest rates. 
deficit. Only the saving glut hypothesis seeks to acknowledge public concern about the trade deficit, and it does so with a pseudo-Keynesian discourse about saving glut. However, analytically it is un-Keynesian, and any problems for the US economy are the result of financial market misallocation of resources and not demand shortage.

\section{THE STRUCTURAL KEYNESIAN EXPLANATION OF GLOBAL FINANCIAL IMBALANCES}

The structural Keynesian hypothesis (Palley 2007/2008; 2012) provides an alternative view of global financial imbalances and explains them as part of the process of neoliberal corporate globalization that took off in the 1980s. From a historical perspective, the completion of the 1979 Tokyo GATT round can be seen to mark the end of the era of free trade and the beginning of the era of corporate globalization that has produced the global imbalances. Table 2 shows the US trade balance by business cycle peak year for the period 1960-2007. From 1960 to 1980, US trade was roughly balanced; but after 1980 the US started running steadily increasing trade deficits that reached 5.9 percent of GDP in 2007.

The critical feature of Table 2 is it shows that the US trade deficit has been a longevolving matter. The profound change in the trade deficit profile occurred around 1980 , reflecting the structural changes associated with the advent of the neoliberal era. Pre-1980, the US trade account was roughly balanced. Post-1980, the trade account began a long, steady descent into significant deficit. ${ }^{5}$

This development was supported by economists, policymakers, and big business. Among economists, free trade continued to be justified and rationalized on the traditional grounds of comparative advantage. However, the addition of inter-temporal consumption choice provided an explanation of and justification for free trade that produces persistent deficits, a feature not present in the standard model of comparative advantage.

Among policymakers, pre-1980 economic thinking was dominated by Keynesian logic, and policymakers viewed trade deficits with concern as they represented a leakage of

Table 2 The US goods and services trade deficit by business cycle peaks, 1960-2007

\begin{tabular}{lrcc}
\hline Peak year & $\begin{array}{c}\text { Trade deficit } \\
\text { (\$ millions) }\end{array}$ & GDP (\$ billions) & $\begin{array}{c}\text { Trade deficit/ } \\
\text { GDP }(\%)\end{array}$ \\
\hline 1960 & 3508 & 526.4 & 0.7 \\
1969 & 91 & 984.6 & 0.0 \\
1973 & 1900 & 1382.7 & 0.1 \\
1980 & -25500 & 2789.5 & -0.9 \\
1981 & -28023 & 3128.4 & -0.9 \\
1990 & -111037 & 5803.1 & -1.9 \\
2001 & -429519 & 10128.0 & -4.2 \\
2007 & -819373 & 13807.5 & -5.9 \\
\hline
\end{tabular}

Sources: Economic Report of the President, 2009 and author's calculations.

5. The US has run a steady surplus on its services account. However, adding in the surplus on services does not change the overall picture. In 1981, the balance on goods and services was $-\$ 16.2$ billion, equal to 0.5 percent of GDP. In 2007 , the balance on goods and services was $-\$ 700.2$ billion, equal to 5.1 percent of GDP. 
aggregate demand (AD). After 1980, with the turn to neoliberal thinking, policymakers have viewed trade deficits as semi-virtuous, because trade helps constrain inflation. Moreover, according to the logic of the new inter-temporal models of trade, deficits are not a bad thing, as they reflect market choices that are supposedly good for the economy.

For big business in the 1980s, trade opening was viewed favorably as a means of disciplining industrial labor unions and reversing the profit-squeeze of the late 1960s and 1970 s. $^{6}$ Subsequently, in the 1990s, trade opening became part of the logic of creating a 'global production zone', in which American firms could either produce for export back to the US or from which they could source cheaper inputs.

Both policymakers and business have therefore seen trade through the lens of costs and wages. For policymakers, trade openness has been a means of constraining inflation. For business, trade openness was initially a means of disciplining workers, and subsequently it has been at the center of a strategy aimed at creating a global production zone in which business could access lowest cost labor.

This congruence of policymaker and big business interests, justified by economists' theories, explains why the era of neoliberal globalization has systematically produced unbalanced trade that culminated in the global financial imbalances problem. The Keynesian free trade era (1945-1980) produced roughly balanced trade because policymakers were averse to large deficits for macroeconomic reasons. In the neoliberal era, policymakers have had little interest in constraining trade deficits, and big business has actively benefitted from deficits.

Corporate globalization rests on a new economic model that can be labeled the global production zone model. The critical development driving the new model has been the increased international mobility of means of production (capital and technology), resulting from improved transportation, communication, and the ability to manage globally diversified production networks. This has created the possibility of global production configured on the principle of global cost arbitrage.

The new reality was captured in the late 1990s by Jack Welch, who was then CEO of General Electric, and who talked of ideally having 'every plant you own on a barge.' The economic logic was that factories should float between countries to take advantage of lowest costs, be they due to under-valued exchange rates, low taxes, subsidies, or a surfeit of cheap labor.

The era of free trade was about encouraging simple cross-border buying and selling of goods and, hence, the policy-focus on tariff reduction. The era of globalization is about multinational corporations creating a new production system based on flexible global production networks. Trade remains central to the global production zone model as goods must cross borders. However, the logic of barge economics is fundamentally different from comparative advantage, though comparative advantage and the theory of free trade are still invoked to provide political cover for the new order. The different logic is evident in the need for investor and property rights protections to sustain FDI, which explains why these rights have become a major focus of so-called 'free' trade agreements. It is also evident in the lack of official concern with balanced trade, and in diminished microeconomic forces for delivering balanced trade, as trade is significantly one-way and shaped by the location of export production platforms.

The global production zone model took off in the 1990s and there were three critical stages to its implementation. Stage 1 was the passage of the North American Free Trade Agreement (NAFTA); stage 2 was the strong dollar policy put in place after the East Asia financial crisis of 1997; and stage 3 was the granting of permanent normal trading relations (PNTR) by the US to China.

6. For a discussion of the profit squeeze hypothesis in the context of the British economy, see Glyn/Sutcliffe (1972). For a discussion in the US context, see Bowles et al. (1989). 


\subsection{Stage 1: NAFTA}

NAFTA fused together the US, Canada, and Mexico into a unified production zone. Its historical significance is that it joined developed and developing economies together for the first time, thereby establishing the template that corporations wanted. It also changed the significance and political economy of exchange rates. Previously, exchange rates mattered principally for trade; after NAFTA, they mattered significantly for location of production. NAFTA also changed corporations' attitude to exchange rates. Before, corporations opposed a strong dollar because it undermined domestic manufacturing competitiveness; after, they increasingly supported a strong dollar because it lowered the price of imported products and raised profit margins. Finally, NAFTA created a critical precedent for strong dollar policy because the US accepted peso devaluation after the Mexican financial crisis of 1994 that accompanied NAFTA's launch.

Table 3 shows the effects of NAFTA on the US-Mexican trade balance, which quickly turned from surplus to deficit and the deficit continued rising thereafter. Within the US economy, manufacturing plants were closed, and production and investment diverted to Mexico (Scott 2001). The threat of shifting jobs to Mexico was also used to suppress wages and batter unions (Bronfenbrenner 2000; Bronfenbrenner and Luce 2004).

\subsection{Stage 2: the strong dollar policy after the East Asia financial crisis of 1997}

The second stage in the 1990s creation of a global production zone was the strong dollar policy implemented after the East Asian financial crisis of 1997. Following the policy precedent of the 1994 Mexican peso crisis, the US helped provide large dollar loans to crisis countries, while countries also let their currencies depreciate. ${ }^{7}$ This policy of depreciation was labeled 'strong dollar' policy, and it was supported by US corporations which were looking to offshore and outsource production. That in turn created a permanent incentive for US corporations to downsize their US manufacturing operations and increase their foreign manufacturing operations, particularly those in East Asia. It was also supported by developing countries because their depreciated exchange rates spurred export-led growth and attracted FDI.

The results are shown in Table 4. There was a massive increase in US trade deficit with Pacific Rim countries, while US manufacturing was put into recession in 1998, 2 years

Table 3 US goods trade balance with Mexico before and after NAFTA (\$ billions)

\begin{tabular}{lcccccccc}
\hline 1991 & 1992 & 1993 & 1994 & 1995 & 1996 & 2000 & 2005 & 2007 \\
\hline 2.1 & 5.4 & 1.7 & 1.3 & -15.8 & -17.5 & -24.5 & -49.7 & -74.6 \\
\hline
\end{tabular}

Source: Census Bureau.

Table 4 US goods trade balance with Pacific Rim countries (\$ billions)

\begin{tabular}{lccccc}
\hline 1995 & 1996 & 1997 & 1998 & 1999 & 2000 \\
\hline-108.1 & -101.8 & -121.6 & -160.4 & -186.0 & -215.4 \\
\hline
\end{tabular}

Source: Census Bureau.

7. The US effectively facilitated crisis countries meeting their foreign currency denominated debt obligations by a combination of repayments using IMF loans, roll-overs, and rescheduling into longer-term debt. 
before the overall economy went into recession. The new arrangement turned the US consumer into the global buyer of first and last resort, making the global economy significantly dependent on the US consumer. That dependence helps explain the global nature of the Great Recession that followed the financial crash of 2008.

\subsection{Stage 3: permanent normal trading relations (PNTR) with China}

NAFTA and the strong dollar policy were disastrous for the economy in terms of their effects on manufacturing, unions and income distribution, and increased dependence on imports. Despite this, big business was still able to push through the establishment of permanent normal trading relations (PNTR) with China, as the full deleterious effects of globalization policy took time to filter through and these effects were also obscured by the asset price bubble of the late 1990s.

PNTR gave China permanent access to US markets with no effective safeguards against China's exchange rate policies and only weak safeguards against unfair trade practices. However, its real significance is that it cemented the structure of globalization that corporations wanted and made China part of global production zone.

Once again, the result was a surge in the US bilateral trade deficit, as shown in Table 5. The trade deficit with China exploded, repeating the pattern of NAFTA and the East Asia strong dollar policy. Corporate profits benefitted but US manufacturing jobs and manufacturing investment suffered. There were also negative effects on Mexico and other developing countries as China siphoned off production and investment, becoming the world's largest recipient of FDI.

Despite the negative impact from China, EM economies were receptive overall to the new arrangements, as they offered access to the US market and the promise of FDI which provides technology, productive capacity, and managerial expertise. This receptiveness is epitomized by Mexico's debate over NAFTA, which was sold to the Mexican people as a pathway to development.

EM economy receptiveness of US-led corporate globalization also reflects the global triumph of neoliberal economic policy. In the 1980s and early 1990s, the IMF and World Bank used the financial leverage provided by the 1980s debt crisis to force neoliberal policy reforms. The price of financial assistance from the IMF and World Bank was the adoption of so-called 'structural adjustment' reforms, which included abandonment of strategic state-led development policies that used strategic import protection.

Structural adjustment policies were justified by a new consensus in the economics profession about the benefits of trade openness and export-led growth. This new consensus claimed the economic success of the four East Asian tigers (South Korea, Hong Kong, Singapore, and Taiwan) proved what was possible - even though none of those economies had actually followed the neoliberal development recipe (Chang 2003).

In sum, the structural Keynesian hypothesis argues that the US trade deficit and global financial imbalances were created by neoliberal corporate globalization that has shaped international economic policy since 1980. Corporate globalization created a structure

Table 5 US goods trade balance with China before and after PNTR (\$ billions)

\begin{tabular}{ccccccccc}
\hline 1998 & 1999 & 2000 & 2001 & 2002 & 2003 & 2004 & 2005 & 2007 \\
\hline-56.9 & -68.7 & -83.9 & -83.1 & -103.1 & -124.1 & -161.9 & -201.5 & -256.2 \\
\hline
\end{tabular}

Source: Census Bureau. 
that inevitably produced large US trade deficits. These deficits were financed via a combination of liberalized financial markets and emerging market countries' willingness to accumulate dollar financial assets. It also created a political economy that justified trade deficits and discouraged policy action to rein in trade deficits. For US policymakers, the strong dollar lowered inflation; for US business, it kept the pressure on union labor and increased profits from foreign sourcing. Consequently, both US policymakers and big business saw benefits from the trade deficit and had no interest in reining it in. In the 1990 s, chatter about the 'New economy' was then used to argue that the US could support the trade deficits because of the faster growth corporate globalization that the 'New economy' supposedly generated. In the 2000s, the US trade deficit was justified by new arguments such as the BW II hypothesis, the dark matter hypothesis, and the asset shortage hypothesis, which argued that the imbalances were beneficial to the US and the global economy.

EM economies supported the new arrangements because they produced trade surpluses that helped relieve financial constraints on growth. They also encouraged massive FDI flows and relocation of manufacturing from developed economies to EM economies, which transferred technology and productive capacity. All of these benefits were supercharged by US exchange rate policy. When US policymakers (but not US big business) eventually began to have modest second thoughts about the benefits of large trade deficits, EM economies frustrated attempts at rebalancing because they still benefitted from the system. Consequently, EM economies have recycled their trade surpluses into dollar reserves to maintain their undervalued exchange rate, and thereby maintain export competitiveness and attractiveness as an FDI destination. ${ }^{8}$ Thus, the accumulation of dollar reserves has been to maintain international price competitiveness, and not to accumulate collateral for FDI as claimed by the BW II hypothesis.

Whereas the BW II hypothesis attributes little direct role to the global financial imbalances in precipitating the financial crisis of 2008, the structural Keynesian hypothesis gives them a significant role. In the BW II story, the global imbalances served to lower US interest rates, which would have been a boon had there not been financial sector resource misallocation. In the structural Keynesian story, the global imbalances sucked consumer demand out of the economy, diverted investment spending offshore, and undermined manufacturing employment and wages. These negative effects contributed to jobless recovery and persistent weakness in the US expansion after the recession of 2001. That in turn prompted the Federal Reserve to reduce interest rates to record lows to support the expansion, and this contributed to the US house price bubble. Moreover, by contributing to the hollowing-out of the US income and demand generation process, the global financial imbalances have contributed to creating the stagnation that has followed the Great Recession of 2007-2009. The stagnation is due to structural demand shortage, which is partly the product of increased wage inequality produced by corporate globalization and de-industrialization.

In addition to explaining the emergence of US trade deficit and global financial imbalances, the structural Keynesian corporate globalization narrative explains why capital has flowed north (that is, why developing countries have run trade surpluses), contrary to conventional growth theory which argues that resources should flow to developing economies where capital is scarce and rates of return higher. The reason is that corporate globalization

8. What constitutes an undervalued exchange rate is a controversial question. Williamson (1983) proposed the concept of fundamental equilibrium exchange rates (FEER) that enable countries to reach a target desired pattern of current account outcomes. Cline (2008) estimates FEERs for the US assuming a target current account deficit equal to 3 percent of GDP. He reports that the yen and renminbi were significantly undervalued in 2008 . 


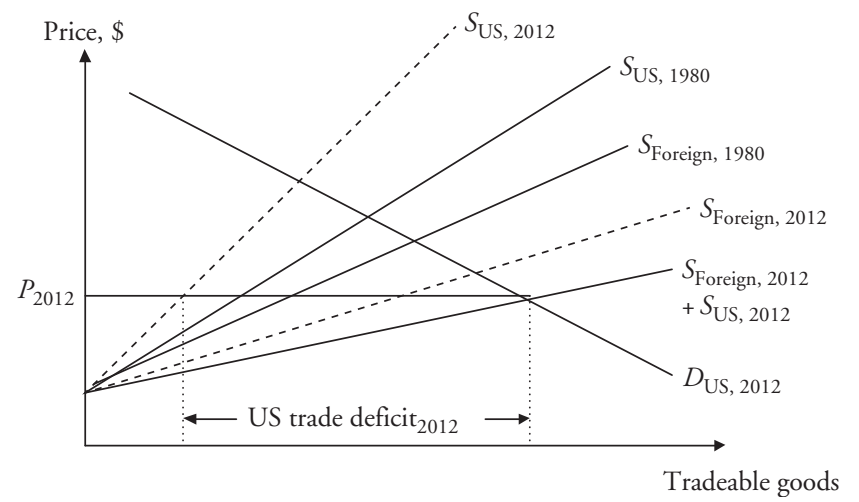

Figure 3 The effect of corporate globalization on the global supply of tradeable goods to the US and on US demand for and supply of tradeable goods

creates a division of labor, where consumers are in the north and producers are in the south. Investment flows south through FDI, though the fruits of that investment (that is, production) flows north. The sustainability of such an arrangement is doubtful, but from the perspective of each firm, and even each country, that is not an issue. For the time being, each supports the system, as each is doing well.

Finally, the structural Keynesian hypothesis provides a clear explanation of why the large US trade deficit has persisted after the financial crisis of $2008 .^{9}$ This explanation is illustrated heuristically in Figure 3, which shows US per-worker demand for tradable goods in 2012, US per-worker supply of tradable goods in 1980 and 2012, and foreign supply of tradable goods to the US in 1980 and 2012 measured in US per-worker terms. All supply schedules are standardized to reflect 2012 levels of productivity. ${ }^{10}$ The essence of the structural Keynesian hypothesis concerns changes on the supply side caused by corporate globalization and EM country development policies, including undervaluation of their currencies. ${ }^{11}$ Between 1980 and 2012, the productivity-adjusted US per-worker supply of tradable goods fell sharply due to de-industrialization, while the productivityadjusted US per-worker foreign supply of tradable goods available to the US expanded due to corporate globalization. Consequently, what would have been a relatively small trade deficit in 1980 at 2012 prices $\left(P_{2012}\right)$, has mushroomed into a massive per-worker deficit in 2012. Absent deep US recession that lowers US income and the demand for imports, the trade deficit inevitably persists because of structural change on the supply side caused by 30 years of corporate globalization policy.

9. With the onset of the Great Recession after the financial crisis of 2008, the US goods trade deficit fell significantly. In 2007 it was $\$ 818.9$ billion, equal to 5.8 percent of GDP. It then fell to $\$ 505.8$ billion in 2009 , equal to 3.6 percent of GDP. It has since risen to $\$ 749.1$ billion in 2012, equal to 4.8 percent of GDP. (Sources: Economic Report of the President 2013 and Commerce Department GDP release, first quarter, 2013.)

10. Supply and demand schedules are constructed in per-worker terms and with constant productivity to capture the pure effects of structural change. Abstracting from productivity and labor force growth enables rough inter-temporal comparison.

11. Abstracting from income effects that affect demand, the impact of undervalued exchange rates can be thought of as analogous to a subsidy to foreign suppliers and shifts the foreign supply down. The reverse holds for a weak dollar. 


\section{THE FALLACY OF THE BW II HYPOTHESIS}

The BW II hypothesis claims to establish a parallel between current global financial arrangements and the pattern of international financial arrangements that ruled from 1945 to 1971 . However, it is difficult to understand that claim.

With regard to economic outcomes, from 1946 to 1971 the US ran a surplus in goods trade in every year except 1971, and the same was true for the balance on goods and services trade. From 1980 to 2011 the US ran a deficit on trade every year, and the same was true for the balance on goods and services trade. Moreover, the absolute size of surpluses in the BW I period was an order of magnitude smaller than the deficits in the putative BW II period. These differences can be seen by comparing Tables 6 and 7. Table 6 shows the goods and services trade balance as a percentage of GDP in peak business cycle year in the BW I period, while Table 7 provides the same data in the BW II period.

Not only were there massive differences on the US international account across the two periods, there were also massive differences regarding the growth and development of the real economy. Tables 8 and 9 show US manufacturing employment levels and growth by business cycle under the BW I and BW II regimes. Under the BW I regime, manufacturing employment grew significantly, though the 1950 s is a complicated decade because the Korean War artificially ratcheted-up employment at the beginning of the decade. Under the BW II regime there has been persistent and accelerating contraction of manufacturing employment, reflecting the de-industrialization of the American economy. As documented in Mishel et al. (2009), the BW I era was also a period of rapidly rising real hourly wages and slightly falling income inequality, whereas the BW II era has been a period of real hourly wage stagnation and significantly increased income inequality.

These fundamental structural differences between the two epochs speak of the inappropriateness of the analogy with BW I, and they also point to several other analytical flaws in

Table 6 US trade surplus by peak business cycle years in the BW I era

\begin{tabular}{cccc}
\hline & $\begin{array}{c}\text { GDP } \\
\text { (\$ billions) }\end{array}$ & $\begin{array}{c}\text { Goods and services } \\
\text { trade balance (\$ billions) }\end{array}$ & $\begin{array}{c}\text { Trade balance as } \\
\text { percent of GDP }(\%)\end{array}$ \\
\hline 1948 & 269.1 & 5.9 & 2.2 \\
1953 & 379.3 & 3.3 & 0.9 \\
1957 & 461.1 & 6.1 & 1.3 \\
1960 & 526.4 & 3.5 & 0.7 \\
1969 & 984.4 & 0.1 & 0.0 \\
\hline
\end{tabular}

Source: Commerce Department and Economic Report of the President, table B-103.

Table 7 US trade surplus by peak business cycle years in the BW II era

\begin{tabular}{cccc}
\hline & $\begin{array}{c}\text { GDP } \\
(\$ \text { billions })\end{array}$ & $\begin{array}{c}\text { Goods and services } \\
\text { trade balance }(\$ \text { billions) }\end{array}$ & $\begin{array}{c}\text { Trade balance as } \\
\text { percent of GDP (\%) }\end{array}$ \\
\hline 1981 & 3126.8 & -16.2 & -0.5 \\
1990 & 5800.5 & -80.9 & -1.4 \\
2001 & 10286.2 & -361.8 & -3.5 \\
2007 & 14028.7 & -696.7 & -4.97 \\
\hline
\end{tabular}

Source: Commerce Department and Economic Report of the President, table B-103. 
Table 8 US manufacturing employment by business cycle peak year under $B W I$

\begin{tabular}{lcc}
\hline Peak year & $\begin{array}{c}\text { Manufacturing } \\
\text { employment (millions) }\end{array}$ & $\begin{array}{c}\% \text { change } \\
\text { peak-to-peak }\end{array}$ \\
\hline 1945 & 14.26 & N/A \\
1948 & 14.32 & 0.4 \\
1953 & 16.13 & 12.6 \\
1957 & 15.80 & -2.05 \\
1960 & 15.44 & -2.27 \\
1969 & 18.57 & 20.27 \\
\hline
\end{tabular}

Table 9 US manufacturing employment by business cycle peak year under $B W I I$

\begin{tabular}{lcc}
\hline Peak year & $\begin{array}{c}\text { Manufacturing } \\
\text { employment (millions) }\end{array}$ & $\begin{array}{c}\text { \% change } \\
\text { peak-to-peak }\end{array}$ \\
\hline 1981 & 18.63 & N/A \\
1990 & 17.70 & -5.00 \\
2001 & 16.44 & -7.12 \\
2007 & 13.88 & -15.57 \\
\hline
\end{tabular}

the hypothesis. First, the deteriorating US trade position of the 1960s was driven by full employment with growing wages, accompanied by a growing manufacturing sector and increasing manufacturing employment. This contrasts with the US trade deficit of the past 20 years, which has been driven by debt-financed consumption spending supported by a house-price bubble. Whereas the US trade position in the 1960s was consistent with a robust and stable aggregate demand generation process, the current system has hollowed out the income and aggregate demand generation process. This hollowing process helps explain the stagnation that has taken hold in the wake of the Great Recession, and it is completely absent in the BW II hypothesis.

Second, the period of the so-called BW II system has seen US multinational corporations shifting production to China to establish state-of-the-art export platforms whose production is intended for export back to the center (the US). This contrasts with the 1950s and 1960s when US multinationals established European production facilities for purposes of supplying the European market. Companies such as Ford, General Motors, and IBM produced in Europe for Europe, not for export back to the United States.

This role of multinationals in driving China's exports and trade surplus is captured in Table 10. The data show that over 50 percent of Chinese exports are produced by 100 percent foreign-owned companies, and over 76 percent of China's exports are produced by foreign-owned companies or joint-venture companies. Thus, both the scale and structure of China's export production are different from Europe's exports in the BW I epoch.

A third criticism of the BW II hypothesis concerns its characterization of the global economic system as being structurally similar in the BW I and BW II periods. Dooley et al. (2003) argue that the global economy has been characterized in both periods by a shared center-periphery structure, with the US the center country in both periods. 
Table 10 Decomposition by firm ownership of the structure of Chinese exports in 2005

\begin{tabular}{cccccc}
\hline & All firms & Foreign-owned & Joint ventures & Private domestic & State-owned \\
\hline Exports & $100 \%$ & 50.4 & 26.3 & 13.1 & 10.3 \\
\hline
\end{tabular}

Source: Manova/Zhang (2008).

However, under BW I, Europe was the periphery, while under BW II, East Asia (and particularly China) has been the periphery. This treatment of Europe and East Asia as structural equivalents is outlandish. After World War II, the European challenge was rebuilding their shattered economies. However, Europe had a highly educated workforce and was a global technological leader in science and engineering. This contrasts with the East Asian challenge in the period 1980-2012 which has been economic development.

A fourth criticism of the BW II hypothesis is lack of evidence for its fundamental claim. The core hypothesis is that China and other East Asian economies have run massive persistent trade surpluses with the US in order to accumulate the collateral needed to provide security for FDI. However, there is no evidence of East Asian country foreign exchange reserves being pledged as collateral for private investment.

A fifth and final criticism concerns the BW II misrepresentation of the microeconomic transactions structure of US-China trade. According to the BW II construction, US consumers engage in an exchange of goods for bonds with Chinese producers so that China finances the US trade deficit. This mischaracterization of China financing the US trade deficit is shared by all mainstream accounts of the trade deficit and reflects their loanable funds approach to saving and investment. The reality is that China sets the terms of exchange via its foreign exchange market interventions, but financing of US purchases is provided by the US financial system that provides the dollars purchased by the Bank of China.

The loanable funds representation of the economics of the trade deficit has misled policymakers and analysts. Thus, before the financial crisis of 2008, the fear was that China would stop accepting US loan notes, causing the dollar to plunge and US interest rates to skyrocket, thereby triggering a financial and economic crisis (Bergsten 2005; Eichengreen 2004; Obstfeld/Rogoff 2007). Indeed, this was the argument used by Nouriel Roubini, who has now become world famous for his astute call of a crash:

The basic outlines of a hard landing are easy to envision: a sharp fall in the value of the US dollar, a rapid increase in US long-term interest rates and a sharp fall in the price of a range of risk assets including equities and housing. (Roubini/Setser 2005: 5)

However, though Roubini's call of a crash was timely, his prediction of how it would play out was entirely wrong. In fact, the dollar strengthened with the crisis and interest rates fell dramatically.

Focusing on a potential exchange rate crash is the natural outcome of the economic analysis underlying both the BW II and other mainstream accounts of financing of the trade deficit. Figure 4 describes the monetary reality of the trade deficit, particularly as it applied during the credit bubble period. The key insight is that the financing of China's export-led growth and the US trade deficit is a two-step intermediated transaction, beginning in the US economy. It is the US financial sector that creates the dollars and liabilities which China eventually comes to hold as foreign exchange reserves. The first step in the process is a transaction between US borrowers (call them consumers) and US banks. This provides households with money (money 1). Households then buy goods from China and 


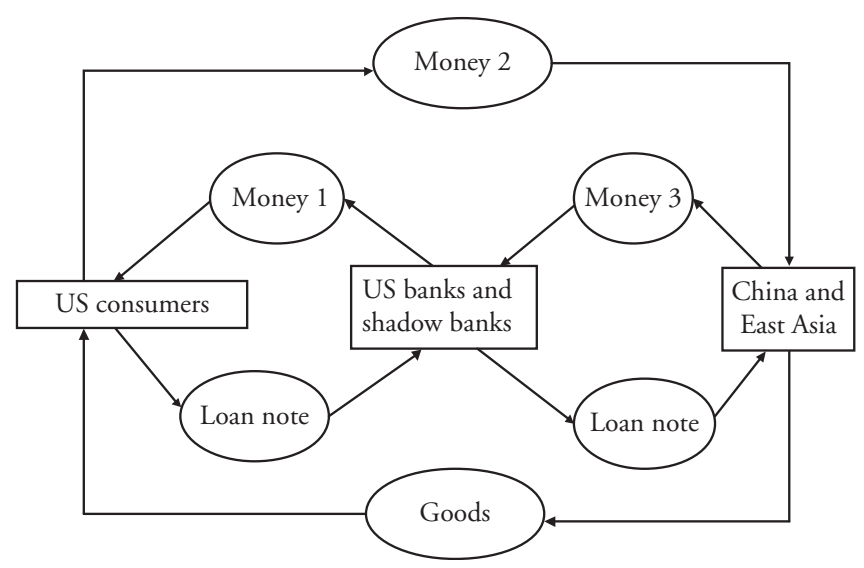

Figure 4 The structure of transactions governing US-China/East Asia trade

in exchange transfer their money balances to China (money 2). China then uses those money balances to purchase loan notes in US financial markets (money 3), which can include purchasing US government debt.

The domestic financial transaction (money 1) can be loosely identified with the provision and demand for credit within the US economy. The last international transaction between China and US financial markets (money 3) is what economists mistakenly describe as China supplying credit and financing the US trade deficit. However, in fact, China supplied the credit when it accepted dollars (money 2). The important feature about Figure 4 is that the system can break down in either the domestic credit market or the market for financial assets. The BW II hypothesis and mainstream economists like Nouriel Roubini focused on asset markets and a sudden stop of financial asset purchases by China. In fact, as predicted by the structural Keynesian hypothesis, the sudden stop occurred in the domestic credit market with the bursting of the house price bubble and a sudden stop to consumer borrowing.

The BW II hypothesis' misunderstanding of the pattern of transactions meant it was of no help in anticipating the crisis or understanding it once it was underway. Now, going forward, it promises to mislead policymakers again by misleading them about future exchange rate developments and needed exchange rate policy.

Looking forward, BW II logic predicts the dollar will weaken as China accumulates reserves, accomplishes its economic development, and has no further need for dollar accumulation as collateral. BW II proponents who believe the process is stable think the depreciation will be slow and gradual. Those who think China's foreign reserve portfolio will become saturated think the depreciation will be sudden and may precipitate another financial crash.

Such reasoning risks inflicting a second episode of policy damage on the US economy. That is because it advocates that China should loosen its capital controls and adopt a flexible exchange rate as part of the process of development and economic maturation. ${ }^{12}$ The

12. China has taken a number of small steps to increase renminbi convertibility. These include issuing renminbi-denominated government debt in Hong Kong; shortening the 
prediction is that the renminbi will slowly appreciate and the dollar will fall as China accumulates adequate reserves, leading to an eventual smooth resolution of global financial imbalances. This thinking now guides US policymaking, and both Federal Reserve Chairman Bernanke and Treasury Secretary Geithner have endorsed this new policy direction, while only criticizing it for being too slow.

Contrary to BW II predictions, having China shift from the current regime of 'quasi-fixed exchange rates plus strict capital controls' to a regime of 'flexible exchange rates plus capital mobility' risks compounding the damage already inflicted on the US economy by past misguided trade and exchange rate policy. The precedent is Japan in the early 1980s. At that time, Japan was running large trade surpluses, had an undervalued exchange rate, and had significant capital account restrictions. Under pressure from the US Treasury, Japan lifted its capital account controls in December 1980 (The Foreign Exchange and Capital Control Law, 1980), yet over the next 2 years the yen depreciated by 20 percent. The reason is Japanese portfolios were internationally undiversified so that removal of capital controls contributed to depreciation of the yen. Outflows from portfolio diversification by residents dominated non-resident inflows.

There is a grave risk this pattern could repeat with China. Chinese citizens have accumulated significant financial wealth which is internationally undiversified. That portfolio structure alone would give Chinese citizens reason to sell renminbi. However, on top of that there are strong political reasons to hold wealth outside China to insure against political dangers. Together, that could cause significant renminbi depreciation in the event of implementation of a flexible exchange-rate-free capital flow regime, which would expose the US to further economic damage. It would also place the US in a politically difficult position, to complain about having received what it asked for.

In addition to this portfolio diversification risk, there is the possibility that China could have its own internal economic bust. Many commentators have speculated about such an outcome, and their reasons include a possible land and house price bubble that may have developed because of excessively easy credit and fears of future inflation in China; excessive fixed investment that has seen China devote 50 percent of its GDP to fixed asset accumulation; and a banking crisis due to accumulated bad loans made to state-owned enterprises and local government. In the event of a Chinese economic crash, the dollar would almost certainly appreciate against the renminbi if exchange rates are flexible and Chinese financial flows are unrestricted.

These structural Keynesian arguments offer a counter to the BW II prediction of future dollar weakness and EM currency strength. They also suggest a different policy course. Neither flexible exchange rates nor free capital mobility is desirable. Instead, China should maintain its system of a pegged exchange rate with capital controls, but the peg should be set to ensure approximately balanced trade.

duration of 'lock-up' periods on certain types of foreign direct investment; increasing the quota for the qualified foreign institutional investor program; increasing the proportion of trade transactions settled in renminbi; and allowing Chinese corporations to retain external foreign currency denominated profits. All of these developments have been met with approval by the US Treasury and the International Monetary Fund. This approval is captured in a speech at the US Export-Import Bank's annual conference in March 2011 when President Obama declared: 'As I've said before, China moving to a more marketoriented exchange rate would make an essential effort to that global rebalancing effort.' 


\section{CONCLUSION}

The BW II hypothesis seeks to draw an analogy between current international financial arrangements and those that ruled in the original Bretton Woods period from 1945 to 1971. Such an analogy is fundamentally misplaced, as there is neither similarity of macroeconomic outcomes nor microeconomic structures. The BW II hypothesis also denies any role of global financial imbalances and the US trade deficit in causing either the crisis or the economic stagnation that has ensued.

Proponents of the BW II hypothesis claim it remains relevant after the financial crisis of 2008 because the large US trade deficit has continued, supposedly proving their point. However, the continuation of large trade deficits is consistent with every other hypothesis and proves little. Dark matter proponents argue dark matter is still in place; asset shortage proponents argue the global economy still has an asset shortage; saving glut proponents argue China still has a saving glut; and structural Keynesian proponents argue the globalization production networks that inevitably produced large trade deficits are unchanged.

Since all of the hypotheses can explain why the US is still running large trade deficits, that cannot be the basis for identifying which hypothesis is right. Instead, the competing hypotheses need to be assessed on the plausibility of their explanation and their fit with the totality of the data. The BW II analogy clearly does not fit the data; it implausibly attributes no role to global imbalances in the making of the US economic crisis and ensuing stagnation; it provides no understanding of the microeconomic transaction structures governing globalization; and it offers little to nothing in the way of testable propositions. All of this argues for its rejection.

The structural Keynesian argument is that the global imbalances are a predictable outcome of policies associated with corporate globalization. That process has been driven and led by US policymakers at the behest of large US transnational corporations, with the intellectual support of mainstream economics. Emerging market policymakers went along with the program, initially under the duress of IMF-enforced structural adjustment, and later willingly via export-led growth. That means US policy has been the ultimate cause of the global imbalances, though not in the way that is claimed in the twin deficits or saving shortage hypotheses. US policymakers did not intend such an outcome, and the policy might not have been adopted had they foreseen it. However, it is still the predictable outcome of their policy choices.

Remedying the problem is difficult as economies are subject to hysteresis. First, whereas China could not have created the imbalances without US support and assistance, it can now obstruct their reduction. Second, the costs to the US may now be quite large as corporations have made significant capital investments in China and East Asia, and US manufacturing has shrunk so that there are now significant domestic supply constraints that would impose further costs.

Whether or not the global imbalances have been good for the US economy depends on one's economic perspective. Those who believe corporate globalization has conferred large benefits, which includes proponents of the BW II hypothesis, think the global imbalances have benefitted the US economy. Those who think corporate globalization has inflicted large costs, which includes proponents of the structural Keynesian hypothesis, would argue the imbalances have injured the US economy and society. The structural Keynesian position is that corporate globalization was intended to shift income from wages to profit by putting labor in international competition via creation of a global production zone.

Because the global imbalances raise such profound matters, it is necessary to sanitize them. That is the political economy function of the many mainstream explanations for the US trade deficit, which include the BW II hypothesis. Hypotheses that sanitize the 
global imbalances are promoted within the mainstream economic profession, while those that paint the imbalances as the product of a toxic form of globalization are ignored. That political economy explains the lop-sided discussion of the global imbalances problem within mainstream academic circles.

\section{REFERENCES}

Bergsten, C.F. (2005): A new foreign economic policy for the United States, in: The United States and the World Economy: Foreign Economic Policy for the Next Decade, Washington, DC: Institute for International Economics.

Bernanke, B.S. (2005): The global saving glut and the US current account deficit, The Sandridge Lecture, Virginia Association of Economics, Richmond, VA, 10 March.

Bernanke, B.S., Bertaut, C., DeMarco, L.P., Kamin, S. (2011): International capital flows and the returns to safe assets in the United States, 2003-2007, International Finance Discussion Papers number 1014, Board of Governors of the Federal Reserve System, Washington, DC, February.

Bowles, S., Gordon, D.M., Weisskopf, T.E. (1989): Business ascendancy and economic impasse: a structural retrospective on conservative economics, in: Journal of Economic Perspectives, 3(1), $107-134$.

Branson, William H. (1974): Stocks and flows in international monetary analysis, in: Ando, A., Herring, R., Marston, R. (eds), International Aspects of Stabilization Policy, Boston: Federal Reserve Bank of Boston, 27-50.

Bronfenbrenner, K. (2000): Uneasy terrain: the impact of capital mobility on workers, wages, and union organizing, Report prepared for the United States Trade Deficit Review Commission, Washington, DC, September.

Bronfenbrenner, K., Luce, S. (2004): The changing nature of corporate global restructuring: the impact of production shifts on jobs in the US, China, and around the globe, Report prepared for the US-China Economic and Security Review Commission, Washington, DC, October.

Caballero, R.J. (2006): On the macroeconomics of asset shortages, NBER Working Paper No.12753, December.

Caballero, R.J. (2007): Understanding global imbalances, Economics at MIT: Research Highlights No. 1.

Chang, H.-J. (2003): Kicking Away the Ladder: Development Strategy in Historical Perspective, London: Anthem Press.

Cline, W.R. (2008): Estimating consistent fundamental equilibrium exchange rates, Working Paper 08-6, Peterson Institute for International Economics, Washington, DC, July.

Dooley, M.P., Folkerts-Landau, D., Garber, P. (2003): An essay on the revised Bretton Woods system, Working Paper 9971, Cambridge, MA: National Bureau of Economic Research, September.

Dooley, M.P., Folkerts-Landau, D., Garber, P. (2004): The US current account deficit and economic development: collateral for a total return swap, Working Paper 10727, Cambridge, MA: National Bureau of Economic Research, August.

Eichengreen, B. (2004): The dollar and the new Bretton Woods system, Manuscript, University of California at Berkeley, December.

Feldstein, M. (1986): The budget deficit and the dollar, in: NBER Macroeconomic Annual, Cambridge, MA: MIT Press, 355-409.

Glyn, A., Sutcliffe, B. (1972): British Capitalism, Workers and the Profits Squeeze, Harmondsworth: Penguin.

Hausmann, R., Sturzenegger, F. (2005): Dark matter makes the US deficit disappear, in: Financial Times, 7 December.

Manova, K., Zhang, Z. (2008): China's exporters and importers: firms, products, and trade partners, Unpublished manuscript, Department of Economics, Stanford University, CA, June.

Mishel, L., Bernstein, J., Allegreto, S. (2009): The State of Working America 2008/2009, Ithaca, NY: Cornell University Press. 
Obstfeld, M., Rogoff, K. (2007): The unsustainable US current account position revisited, in: Clarida, Richard (ed.), G7 Current Account Imbalances: Sustainability and Adjustment, Chicago: University of Chicago Press.

Palley, T.I. (2007/2008): The fallacy of the revised Bretton Woods hypothesis: why today's system is unsustainable and suggestions for a replacement, in: International Journal of Political Economy, 36 (Winter), 36-52. (Originally published as Public Policy Brief No. 85, The Levy Economics Institute of Bard College, 2006.)

Palley, T.I. (2012): From Financial Crisis to Stagnation: The Destruction of Shared Prosperity and the Role of Economics, Cambridge, UK: Cambridge University Press.

Roubini, N., Setser, B. (2005): Will the Bretton Woods 2 regime unravel soon? The risk of a hard landing in 2005-2006, Paper prepared for a conference organized by the Federal Reserve Bank of San Francisco, February, URL: http://www.frbsf.org/economics/conferences/0502/Roubini.pdf. Scott, R.E. (2001): NAFTA at seven: its impact on workers in all three nations, Briefing Paper, Economic Policy Institute, Washington DC, April.

Tobin, J., Braga de Macedo, J.A. (1980): The short-run macroeconomics of floating exchange rates: an exposition, in: Chipman, John S., Kindelberger, Charles P. (eds), Flexible Exchange Rates and the Balance of Payments, Amsterdam: North-Holland, 5-28.

Williamson, J. (1983): The Exchange Rate System, Policy Analysis in International Economics, 5, Washington: Institute for International Economics. 